\title{
The first pilot study of expanded newborn screening for inborn errors of metabolism and survey of related knowledge and opinions of health care professionals in Hong Kong
}

Chloe M Mak, Eric CY Law, Hencher HC Lee, WK Siu, KM Chow, Sidney KC Au Yeung, Hextan YS Ngan, Niko KC Tse, NS Kwong, Godfrey CF Chan, KW Lee, WP Chan, SF Wong, Mary HY Tang, Anita SY Kan,

Amelia PW Hui, PL So, CC Shek, Robert SY Lee, KY Wong, Eric KC Yau, KH Poon, Sylvia Siu, Grace WK Poon, Anne MK Kwok, Judy WY Ng, Vera CS Yim, Grace GY Ma, CH Chu, TY Tong, YK Chong, Sammy PL Chen, CK Ching, Angel OK Chan, Sidney Tam, Ruth LK Lau, WF Ng, KC Lee, Albert YW Chan, CW Lam *

\section{A B S T R A C T}

Introduction: Newborn screening is important for early diagnosis and effective treatment of inborn errors of metabolism (IEM). In response to a 2008 coroners' report of a 14-year-old boy who died of an undiagnosed IEM, the OPathPaed service model was proposed. In the present study, we investigated the feasibility of the OPathPaed model for delivering expanded newborn screening in Hong Kong. In addition, health care professionals were surveyed on their knowledge and opinions of newborn screening for IEM.

Methods: The present prospective study involving three regional hospitals was conducted in phases, from 1 October 2012 to 31 August 2014. The 10 steps of the OPathPaed model were evaluated: parental education, consent, sampling, sample dispatch, dried blood spot preparation and testing, reporting, recall and counselling, confirmation test, treatment and monitoring, and cost-benefit analysis. A fully automated online extraction system for dried blood spot analysis was also evaluated. A questionnaire was distributed to 430 health care professionals by convenience sampling.

Results: In total, 2440 neonates were recruited for newborn screening; no true-positive cases were found. Completed questionnaires were received from 210 respondents. Health care professionals supported implementation of an expanded newborn screening for IEM. In addition, there is a substantial need of more education for health care professionals. The majority of respondents supported implementing the expanded newborn screening for IEM immediately or within 3 years.

Conclusion: The feasibility of OPathPaed model has been confirmed. It is significant and timely that when this pilot study was completed, a governmentled initiative to study the feasibility of newborn screening for IEM in the public health care system on a larger scale was announced in the Hong Kong
Special Administrative Region Chief Executive Policy Address of 2015.
Hong Kong Med J 2018;24:226-37

DOI: $10.12809 / \mathrm{hkmj} 176939$

CM Mak, MD, FHKAM (Pathology)

${ }^{2,3}$ ECY Law, PhD, FHKAM (Pathology)

${ }^{1}$ HHC Lee, MA, FRCPA

WK Siu, PhD, FHKAM (Pathology)

${ }^{4}$ KM Chow, FRCOG, FHKAM (Obstetrics and Gynaecology)

${ }^{5}$ SKC Au Yeung, FRCOG, FHKAM (Obstetrics and Gynaecology)

${ }^{6}$ HYS Ngan, FRCOG, FHKAM (Obstetrics and Gynaecology)

NKC Tse, FHKCPaed, FHKAM (Paediatrics)

${ }^{8}$ NS Kwong, FHKCPaed, FHKAM (Paediatrics)

${ }^{9}$ GCF Chan, FHKCPaed, FHKAM (Paediatrics)

${ }^{4}$ KW Lee, FRCOG, FHKAM (Obstetrics and Gynaecology)

${ }^{4}$ WP Chan, MB, ChB, FHKAM (Obstetrics and Gynaecology)

${ }^{5}$ SF Wong, FRCOG, FHKAM (Obstetrics and Gynaecology)

${ }^{6}$ MHY Tang, FRCOG, FHKAM (Obstetrics and Gynaecology)

${ }^{6}$ ASY Kan, MRCOG, FHKAM (Obstetrics and Gynaecology)

${ }^{6}$ APW Hui, FRCOG, FHKAM (Obstetrics and Gynaecology)

${ }^{5}$ PL So, FRCOG, FHKAM (Obstetrics and Gynaecology)

${ }^{7}$ CC Shek, FHKCPaed, FHKAM (Paediatrics)

${ }^{7}$ RSY Lee, FHKCPaed, FHKAM (Paediatrics)

${ }^{9} \mathrm{KY}$ Wong, FHKCPaed, FHKAM (Paediatrics)

${ }^{7}$ EKC Yau, FHKCPaed, FHKAM (Paediatrics)

${ }^{8}$ KH Poon, MRCP(UK), FHKCPaed

${ }^{8}$ S Siu, MB, ChB, FHKAM (Paediatrics)

${ }^{9}$ GWK Poon, FHKCPaed, FHKAM (Paediatrics)

${ }^{9}$ AMK Kwok, FHKCPaed, FHKAM (Paediatrics)

${ }^{4}$ JWY Ng, BAppSc(Nurs), MSSc (Counselling)

${ }^{5}$ VCS Yim, FHKAN (HKCMW), MSC

${ }^{6}$ GGY Ma, BSN, MHSM (Health Services Management)

${ }^{10} \mathrm{CH}$ Chu, ms

${ }^{1}$ TY Tong, MSc

${ }^{1}$ YK Chong, FHKCPath, FHKAM (Pathology)

${ }^{1}$ SPL Chen, FRCPA, FHKAM (Pathology)

${ }^{1}$ CK Ching, FRCPA, FHKAM (Pathology)

${ }^{3}$ AOK Chan, MD, FHKAM (Pathology)

${ }^{4}$ S Tam, FRCP, FHKAM (Pathology)

${ }^{11}$ RLK Lau, MB, ChB, FHKAM (Pathology)

${ }^{11}$ WF Ng, MB, ChB, FHKAM (Pathology)

${ }^{1}$ KC Lee, MB, ChB, FHKAM (Pathology)

${ }^{1}$ AYW Chan, MD, FHKAM (Pathology)

${ }^{2}$ CW Lam *, PhD, FHKAM (Pathology)

Chemical Pathology Laboratory, Department of Pathology, Princess Margaret Hospital, Kwai Chung, Hong Kong

2 Department of Pathology, The University of Hong Kong, Queen Mary Hospital, Pokfulam, Hong Kong

Division of Clinical Biochemistry, Queen Mary Hospital, Pokfulam, Hong Kong

Department of Obstetrics and Gynaecology, Princess Margaret Hospital, Kwai Chung, Hong Kong 
${ }^{5}$ Department of Obstetrics and Gynaecology, Tuen Mun Hospital, Tuen Mun, Hong Kong

${ }^{6}$ Department of Obstetrics and Gynaecology, Queen Mary Hospital, Pokfulam, Hong Kong

Department of Paediatrics and Adolescent Medicine, Princess Margaret Hospital, Kwai Chung, Hong Kong

${ }^{8}$ Department of Paediatrics and Adolescent Medicine, Tuen Mun Hospital, Tuen Mun, Hong Kong

${ }^{9}$ Department of Paediatrics and Adolescent Medicine, Queen Mary Hospital, Pokfulam, Hong Kong

${ }^{10}$ Department of Pathology, United Christian Hospital, Kwun Tong, Hong Kong

${ }^{11}$ Department of Pathology, Yan Chai Hospital, Tsuen Wan, Hong Kong

* Corresponding author: ching-wanlam@pathology.hku.hk

\section{Introduction}

The expansion of newborn screening (NBS) for various genetic disorders with a focus on inborn errors of metabolism (IEM) has become a mandatory part of health care policy worldwide. Multiplex testing by tandem mass spectrometry has extended the scope of NBS far beyond the traditional one test for one disease' paradigm, requiring only a tiny blood sample, obtained by a simple heel prick. ${ }^{1,2}$ As a result, many inherited diseases are now screened for to allow early diagnosis and intervention and thereby prevent permanent damage or potential deaths.

Inborn errors of metabolism are a group of rare metabolic diseases with heterogeneous clinical presentations and genetic aetiologies. They are individually rare but collectively common. In 2011, Lee et $\mathrm{al}^{3}$ reported a 5 -year retrospective review on the laboratory diagnosis of amino acid disorders, organic acidurias, and fatty acid beta-oxidation defects in three regional hospitals. The overall local incidence of classical IEM was 1 in 4122 live births. ${ }^{3}$ No phenylketonuria was identified through the screening of 18000 newborns in the early 1970s. ${ }^{4}$ Hyperphenylalaninaemia was the second most common amino acid disorder reported by Lee et $\mathrm{al}^{3}{ }^{3}$ with an incidence of 1 in 29542 live births. Another study by Hui et $\mathrm{al}^{5}$ reported the overall incidence of common IEM as 1 in 5400. According to the Hong Kong Paediatric Metabolic Registry, there were two cohorts, the first one with 20 years from 1982 to

\section{全港首個新生兒先天性代謝病篩檢先導研究及香 港醫護人員的相關知識意見問卷調查 \\ 麥苗、羅震耀、李漢芝、蕭慧君、周鑑明、歐陽錦全、 \\ 顏婉嫦、謝紀超、䣝毅山、陳志峰、李啟雲、陳運鵬、 \\ 王世芬、唐海燕、簡適悠、許佩華、蘇寶琳、石志超、 \\ 李誠仁、黃嘉賢、丘健昌、潘建雄、蕭鑾儀、潘永潔、 \\ 郭美均、吳惠英、嚴清秀、馬家儀、朱就雄、唐芷欣、 \\ 張耀君、陳柏林、程楚君、陳安琪、譚志輝、劉蓮嬌、 \\ 吳維富、李錦昌、陳恩和、林青雲}

引言：新生兒篩查有助及早診斷和有效治療先天性代謝病（IEM）。 針對2008年一名死於未確診先天性代謝病的 14 歲男孩的死因裁判官報 告, 有建議提出OPathPaed服務模型。本研究檢視OPathPaed模型對 香港擴大新生兒篩查的可行性, 也查訪醫護人員對新生兒先天性代謝 病篩檢的認識和意見。

方法：2012年10月 1 日至2014年8月 31 日期間，對三家地區醫院分階 段進行前瞻性研究, 評估OPathPaed模型的 10 個步驟：父母教育、知 情同意、抽樣、乾血點樣本運送、乾血點準備和測試、報告、患者召 回和諮詢、確認測試、治療和監測, 以及成本效益分析, 以及評估用 作分析乾血點的全自動在線提取系統。研究以便利抽樣方式向430名 醫護人員發放問卷。

結果：共納入 2440 名新生兒進行篩檢, 沒有發現真陽性病例。共收到 210 名受訪者的完整問卷。醫護人員支持擴大新生兒先天性代謝病篩 檢, 以及極須加強對醫護人員相關的教育。此外, 大部份受訪者支持 立即或3年內擴大新生兒先天性代謝病篩檢。

結論：OPathPaed模型的可行性已得到證實。在這項先導研究完成之 時, 政府在 2015 年施政報告中提出由政府牽頭研究在公共醫療體系中 進行更大規模新生兒先天性代謝病篩檢的可行性, 這是具重要意義和 適時的

2002 with 89 IEM patients and the second one with 14 years from 1996 to 2010 with 120 IEM patients. The estimated incidence of IEM was 1 in 7580 (unpublished data); however, as that was a voluntary case-finding study from several hospitals, the incidence was likely to be an underestimate. These figures are similar to those reported worldwide, such as 1 in 5800 in mainland China, ${ }^{6} 1$ in 5882 in Taiwan, ${ }^{7}$ and 1 in 4000 in America. ${ }^{8}$

In 2000, a mandatory NBS programme for hyperphenylalaninaemia, congenital hypothyroidism, and congenital deafness was implemented in mainland China. ${ }^{9}$ In 2006,

\section{New knowledge added by this study}

- The feasibility of the OPathPaed service model was evaluated in 2440 neonates. The main focus was on parental education, consent, sampling, sample dispatch, dried blood spot preparation and testing, reporting, recall, and counselling.

- Of 210 health care professionals who responded to a survey, $73.6 \%$ were unaware of newborn screening for inborn errors of metabolism (IEM), 87.6\% urged for more education, and 91.3\% supported implementing expanded newborn screening for IEM immediately or within 3 years.

Implications for clinical practice or policy

- The OPathPaed service model for implementing expanded newborn screening for IEM is feasible for local public hospital settings.

- Health care professionals support implementation of newborn screening for IEM. In addition, there is a substantial need of more education. 
the American College of Medical Genetics recommended 29 metabolic diseases (IEM) for which screening should be mandated. ${ }^{10}$ Since then, the scope of this recommendation has been expanding (Recommended Uniform Screening Panel, the Secretary of the Department of Health and Human Services $\left.{ }^{11}\right) .{ }^{12}$ In Hong Kong, population screening for congenital hypothyroidism and glucose-6phosphate dehydrogenase (G6PD) deficiency using umbilical cord blood has been mandatory since March 1984 under the Neonatal Screening Unit of the Clinical Genetic Service, Department of Health. This programme has resulted in a significant reduction in related morbidities and mortalities.

In 2008, a coroner inquest was called to investigate the sudden death of a 14-year-old boy with a postmortem genetic diagnosis of glutaric acidaemia type II. ${ }^{13}$ The Coroners' Report demanded that "The Department of Health, the Hospital Authority, the Faculty of Medicine of various universities and others concerned should carry out a feasibility study to see whether universal check may be carried out on all newborn babies for congenital metabolism defect." ${ }^{14}$

To be effective, an expanded NBS programme needs to be coupled with improved general awareness of IEM and NBS. Educational support and training are required for frontline clinicians engaged in the diagnosis and care of patients with IEM. ${ }^{15}$ Several studies have shown that health care professionals do not have satisfactory awareness and knowledge of IEM. ${ }^{15-18}$ Therefore, a better understanding of the awareness of IEM among health care professionals in Hong Kong is needed.

We have conducted the first feasibility pilot study on the expanded NBS service model in a hospital setting in Hong Kong and the first survey on the knowledge and opinions on NBS for IEM among health care professionals in Hong Kong.

\section{Methods}

This prospective pilot study was conducted in phases from 1 October 2012 to 31 August 2014, involving three public hospitals and The University of Hong Kong (HKU), with over 40 collaborators from departments of pathology, paediatrics, and obstetrics. Phases 1 and 2 involved a single-site study conducted at Princess Margaret Hospital from 1 October 2012 to 31 October 2013 and then at Tuen Mun Hospital from 1 November 2013 to 31 March 2014. Phase 3 was university (HKU)-based and the recruitment was open to the public from 3 March 2014 to 31 August 2014. Phase 4 was a two-site study at the Tuen Mun Hospital and Queen Mary Hospital from 4 April 2014. Phase 5 was carried out at all three hospitals from 2 July 2014 until 31 August 2014. The OPathPaed model for expanded NBS was used for evaluation. ${ }^{19}$ The OPathPaed model includes
10 steps: parental education, consent, sampling, sample dispatch, dried blood spot (DBS) preparation and testing, reporting, recall and counselling, confirmation test, treatment and monitoring, and cost-benefit analysis (Fig 1).

\section{Pilot study to investigate the feasibility of the 10-step OPathPaed model}

\section{Step 1: Parental education}

Educational talks were delivered by chemical pathologists during antenatal visits. With the help of the Save Babies Through Screening Foundation, we added Chinese subtitles to the video titled "Newborn Screening Saves Babies One Foot at a Time". The video is available online (https://www.youtube.com/ watch?v=dxFit_a601w). DVDs and a locally designed pamphlet with an email address and telephone number for enquiries were distributed to expectant mothers (Fig 2). In order to raise public awareness, several interviews with the media were arranged and reports were published in several newspapers ${ }^{20-22}$ and radio and television programmes..$^{23,24}$

\section{Step 2: Obtaining consent}

A consent form was designed for NBS for IEM (data not shown). Educational videos and pamphlets were used to inform the parents. Written informed consent was collected during a postnatal talk after the education session. The talk was conducted in group presentation for the mothers by chemical pathologists.

\section{Step 3: Sampling}

Paediatricians or pathologists organised training for phlebotomists on the heel prick technique, in compliance with the Clinical and Laboratory Standard Institute guidelines. ${ }^{25}$ An instruction sheet with photographs of valid and invalid DBS samples was provided as guidance for the phlebotomists (Fig 3). Samples were collected from neonates aged between 24 hours and 28 days.

\section{Step 4: Dried blood spot dispatching}

Drying racks and special boxes designed for specimen transport before complete drying were delivered to the testing sites. Complete drying of blood spots was ensured for valid sample integrity. The blood spot cards were dried perpendicular to each other above and below the rack position to avoid contact contamination between blood spots of different patients.

\section{Step 5: Dried blood spot preparation and testing}

Two commercial DBS assay kits: (1) MassChrom Amino Acids and Acylcarnitines from Dried Blood/ Non-derivatised (Chromsystems Instruments 


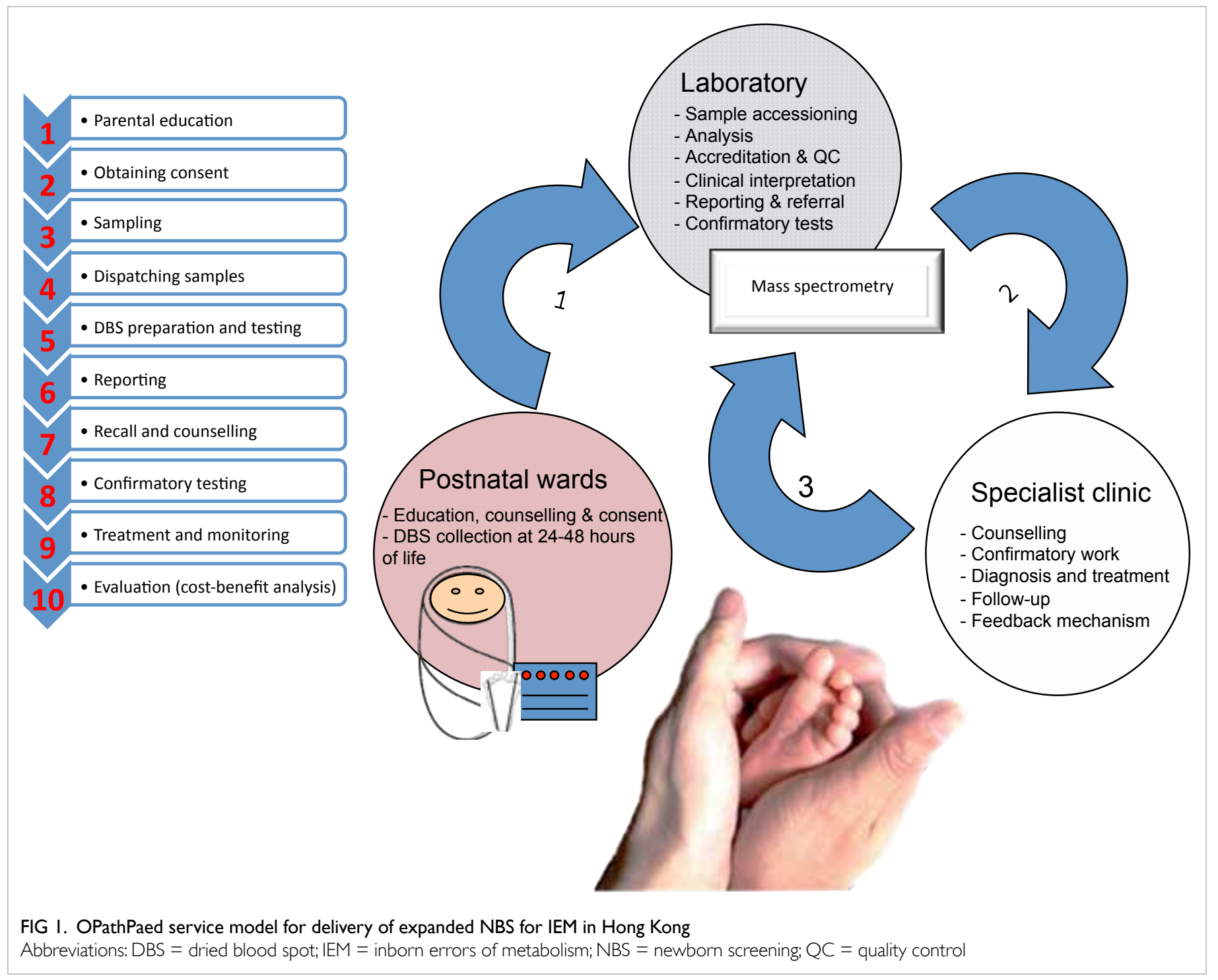

\& Chemicals GmBH, Gräfelfing, Germany); and (2) NeoBase Non-derivatized MSMS kit (with succinylacetone assay; PerkinElmer, Waltham [MA], US) were validated for use in the study. In addition to a manual puncher and an autopuncher for DBS preparation, a fully automated online extraction system (DBS-MS 500; CAMAG, Muttenz, Switzerland) was also evaluated. The precision and local reference intervals of the commercial assay kits are listed in Table 1. Our laboratory has participated in the Newborn Screening Quality Assurance Programme organised by the US Centers for Disease Control and Prevention (CDC) since 2011. The disease panel included in the study is shown in Table 2.8,10,11

\section{Step 6: Reporting}

Chemical pathologists were responsible for reporting of positive results to the paediatricians. The CDC cut-off for clinical decision (https://wwwn.cdc.gov/ NSQAP/Restricted/CDCCutOffs.aspx) and the Region 4 Stork Collaborative Project (https://www.

clir-r4s.org/) data interpretation tools were applied during interpretation of the results.

\section{Step 7: Recall and counselling}

Newborn Screening ACT Sheets and Confirmatory Algorithms by the American College of Medical Genetics (https://www.ncbi.nlm.nih.gov/books/ NBK55827/) were followed for patient recall. All abnormal results were examined by chemical pathologists. These chemical pathologists were also responsible for contacting the parents for post-test counselling and for arranging subsequent hospital referrals for care by paediatricians.

\section{Step 8: Confirmation test}

Confirmation of diagnosis was provided by regional laboratories through measurements of functional metabolites (mainly plasma amino acid levels, plasma acylcarnitine levels, and urine organic acid levels) and genetic diagnosis by DNA sequencing wherever appropriate. 
遺傳疾病是每個新生命都需要面對的風險 遺傳代謝疾病很多時候只是缺乏某種醭素 如果能夠及早發現，及早治療 很多患病小朋友都可以健康正常成長 可惜的是，診斷遺傳代謝疾病非常困難

現時世界很多地方設有初生嬰兒遺傳疾病篩查 希望每個小朋友出生後都能及早接受檢驗 一旦發現異常，可以及早複檢確認 一旦確診患上遺傳疾病，也能及早接受正確治療

香港大學李嘉誠醫學院病理學系 余兆麒醫療基金

\section{二代新生嬰兒笠檢 先導研究計劃}

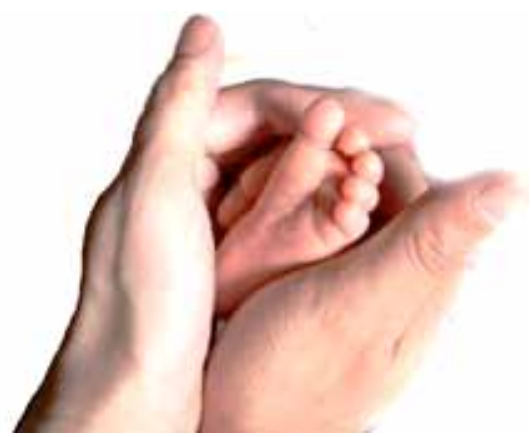

甚麼是新生嬰兒篩檢？

新生嬰兒篩檢是在嬰兒出生後進行的檢查, 目的是及早診斷某些嚴重的疾病, 令病人可以及 早接受正確的治療。

現時政府提供的免費新生嬰兒篩檢包括以 臍帶血篩檢甲狀腺功能不足以及蟫豆症。

\section{二代新生嬰兒篩檢有何特別？}

傳統的新生嬰兒篩檢可能只會測試一兩種 疾病。二代新生嬰兒篩檢利用了現今先進的醫療 科技, 以一部名為 $\ulcorner$ 串聯質譜」的儀器量度血液 裡的多種代謝物質, 一次便可以進行幾十種遺傳 疾病的測試。現時世界很多國家包括美加、澳 紐、日本、台灣、新加坡及中國大陸等地, 都已 經設有這類二代新生嬰兒篩檢的計劃。

\section{甚麼叫做遺傳代謝疾病？}

遺傳疾病是由基因缺陷所造成的。如果這些 基因缺陷造成新陳代謝方面的問題, 例如缺乏某 種酵素或者其他物質, 令到毒素積聚, 或者影響 身體未能獲取所需能量, 便叫做遺傳代謝疾病。

根據本地統計數據估計, 香港約每 4000 個初生嬰兒就有一個患有這類罕見遺傳疾病, 數 字上和其他鄰近地區大致相同。

甚麼是 $\Gamma$ 刮腳板」?

$「$ 刮腳板」是腳跟穿刺術的俗稱, 其實是特 別為初生嬰兒而設的抽血方法, 各大醫院已經沿 用多年, 相當安全。
我的嬰兒還小, 可以遲些才接受篩檢嗎?

儘管遺傳代謝疾病由初生嬰兒至青少年時期 也有機會發病, 最嚴重的類型往往在出生頭幾天 就出現病徵。由於這些代謝疾病種類極為繁多, 而又相對罕見, 以致診斷非常困難 ; 偏偏治療這 類疾病卻是爭分奪秒。在沒有二代篩檢計劃的情 況之下, 這些病人大部分都延至發病人院一段時 間才作出正確診斷, 即使撿回一命, 往往也為時 太晚, 以致需要接受特殊教育或者長期住宿院 舍。因此及早診斷, 及早治療, 對代謝疾病的孩 子而言是非常重要的

\section{我要怎樣參加這個研究計劃?}

研究人員會詳細為你解釋這項計劃的細節, 獲得你的書面同意之後, 研究人員會在嬰兒出生 24小時後「刮腳板」抽取少量血液, 滴在特製試 紙上, 再送往化學病理化驗室進行 MSMS 測 試。參加這項研究計劃是屬於自願性質的, 費用 全免。

\section{我怎樣知道篩檢的結果？}

一般來說, 如果篩檢的結果屬於正常, 你不 會特別收到通知。須要注意此項篩檢結果正常, 並不能代表孩子日後必定沒有其他種類的遺傳疾 病。

如果篩檢結果不正常，懷疑孩子患有遺傳代 謝疾病, 醫護人員會在一星期內以電話聯絡你, 為孩子安排覆檢。一旦確診某種遺傳代謝疾病, 也會及早安排孩子接受專科治療。
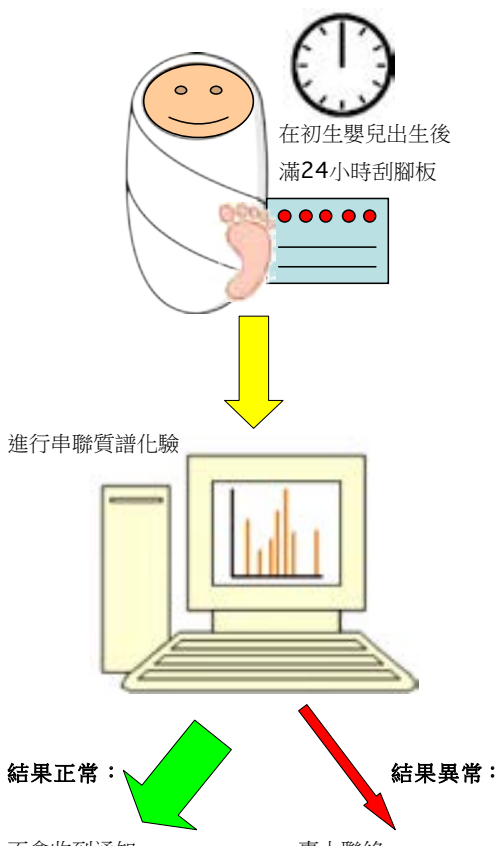

不會收到通知

專人聯絡
香港大學李嘉誠醫學院病理學系邀請你和你 的初生嬰兒參加這項名為 $\ulcorner$ 二代新生嬰兒篩檢先導 研究」的計劃。這項計劃由余兆麒醫療基金資助, 現階段為本醫院出生的新生嬰兒提供遺傳代謝疾 病篩檢, 研究目的包括確立本港落實進行二代篩檢 的診斷流程及化驗參考數值, 提供本港遺傳疾病實 證統計數據, 以及探討二代篩檢在心理、社會及倫 理方面對本港家庭的影響。

研究人員會詳細為你解釋這項計劃的細節。獲 得你的書面同意之後, 研究人員會在嬰兒出生 24 小時後「刮腳板」抽取少量血液, 滴在特製試紙上, 再送往化學病理化驗室, 以一部名為「串聯質譜」 (MSMS) 的儀器量度血液裡的代謝物質, 一次過 進行大約二十種遺傳代謝疾病的測試。一旦化驗結 果異常, 我們會盡快聯絡你, 為你的孩子安排覆診 及相關治療。

如有任何關於本研究的查詢,

請於辦公時間聯絡研究人員 : (852) Xxxx Xxxx

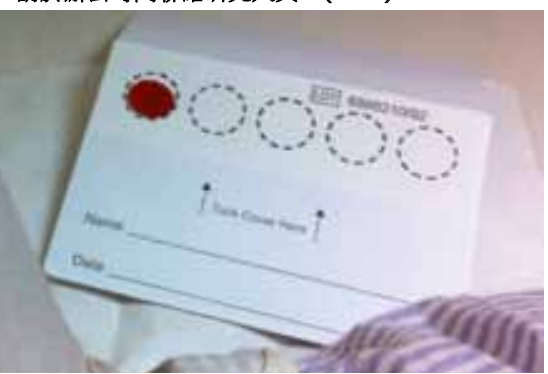

為何我的嬰兒需要接受穊檢?

遺傳疾病是每個新生命都需要面對的風

險。遺傳代謝疾病如果能夠及早發現, 及早治療, 很有可能避免器官異常、發展遲緩、殘障甚至死 亡等嚴重後果；只要按時服藥, 很多患病小朋友 都可以健康正常成長

\section{我的嬰兒似乎很正常, 為甚麼需要接受篩檢？}

遺傳代謝疾病可以在任何一個新生嬰兒身 上出現。絕大部份遺傳代謝疾病的病人在早期並 沒有明顯病徵, 可是新陳代謝方面的問題不知不 覺已經影響到各種身體機能, 造成腦部及其他器 官的損傷。即使發病, 起初可能也只是疲倦、不 願進食、呼吸急促或者發出古怪氣味等不明顯徵 狀, 但情況可以隨時急轉直下, 造成器官衰竭、 嚴重後遺症或者生命危險。接受篩檢能夠及早診 斷出這類疾病, 是最安全的做法

我們家人很健康，有機會有遺傳代謝疾病嗎？

人體有三萬多個基因, 數目如此大, 多多少 少總會有些瑕疪; 而這些基因都是一對一對的, 每對的兩邊都是遺傳自父母雙方。以隱性遺傳疾 病來說, 即使父母和所有家人都非常健康, 可是 如果父母雙方碰巧在同一個基因上都有缺陷, 或 者基因碰巧發生突變, 令小朋友剛好遺傳到一對 兩邊都有缺陷的基因, 健康家庭的下一代也可以 患上這些遺傳疾病。

FIG 2. Chinese version of pilot study pamphlet on newborn screening for inborn errors of metabolism 
Valid samples showing sufficient native whole blood, single layer, homogeneous saturation, thorough soak-through from top to bottom surface, completely dried spots, and lack of signs of contamination, such as diluted appearance, serum rings, or scratch marks
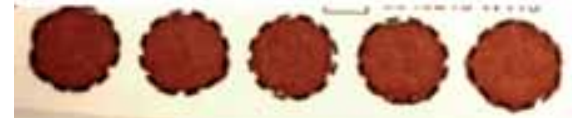

Invalid samples:

Insufficient sample quantity for testing

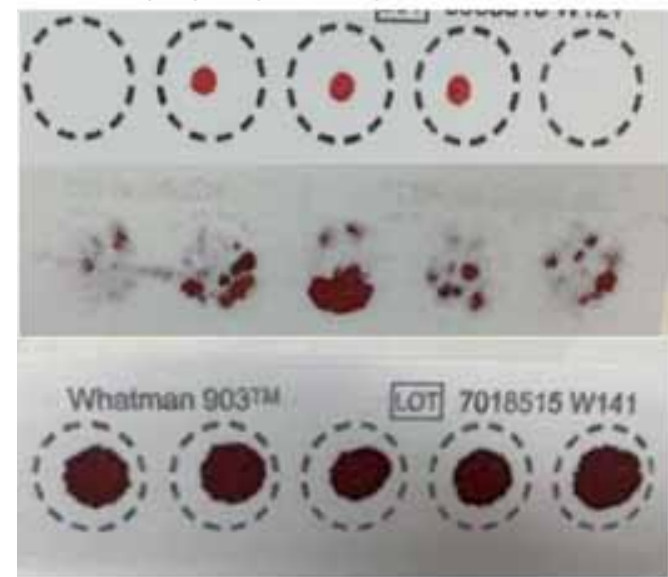

Scratched or abraded sample

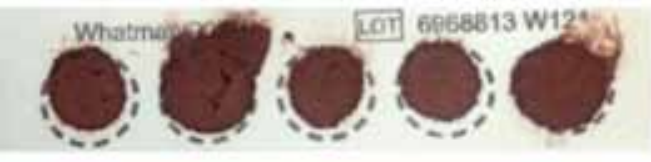

Incompletely dried sample

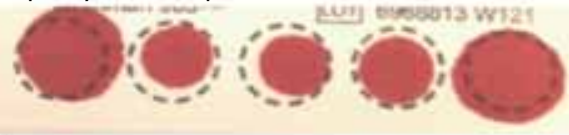

Sample with serum rings

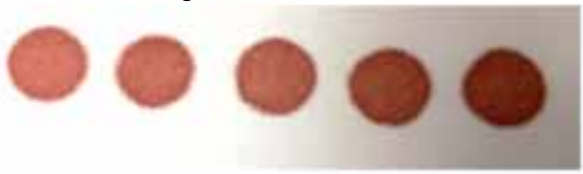

Specimen appears diluted, discoloured, or contaminated

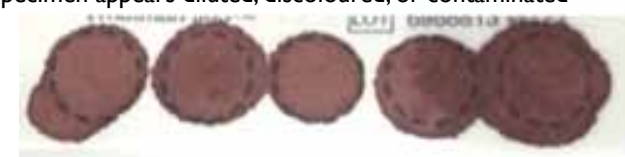

Layered sample

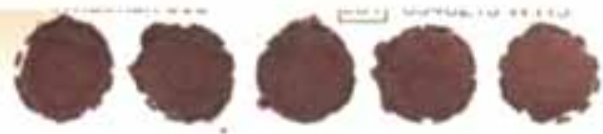

Clotted sample

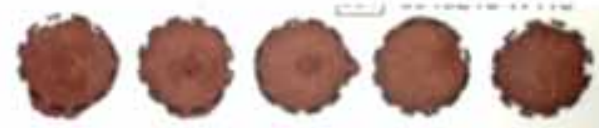

Oversaturated sample

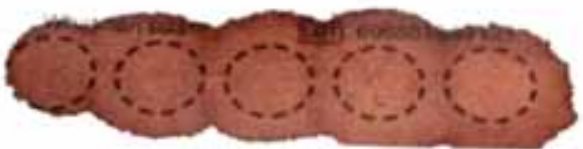

No blood

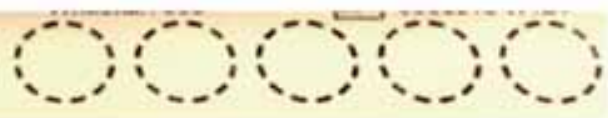

FIG 3. Instruction guide with examples of valid and invalid dried blood spot samples

\section{Step 9: Treatment and monitoring}

Admission logistics and treatment protocols for neonatal units with on-call rosters were established by hospital paediatricians. The same regional laboratories mentioned in Step 8 continued to provide biochemical diagnostic services.

\section{Step 10: Cost-benefit analysis}

A cost-benefit analysis has been conducted and published previously. ${ }^{26}$ Hyperphenylalaninaemia due to 6-pyruvoyl-tetrahydropterin synthase deficiency was used as an example to evaluate the costs and benefits of implementing an expanded NBS programme in Hong Kong. Assuming an annual birth rate of 50000 and hyperphenylalaninaemia incidence of 1 in 29542 live births, the annual medical costs and adjusted loss of workforce would be HK\$20 773 207. The implementation and operational costs of an expanded NBS programme are expected to be HK\$10473848 annually. Thus, implementing the expanded NBS programme is expected to result in an annual saving of $\mathrm{HK} \$ 9632750 .^{26}$

\section{Survey of health care professionals' knowledge and opinions of newborn screening for inborn errors of metabolism}

A questionnaire was distributed by convenience sampling to 430 health care professionals who worked in hospitals and were not involved in the pilot study. These self-administered questionnaires were distributed to local health care professionals including medical doctors, nurses, and other allied health care professionals either in person with returning envelopes or via email to department heads for further distribution. The self-administered questionnaire in English was modified from a previously published questionnaire that was tested among parents. $^{27}$ The self-administered questionnaire included 13 questions that covered the local practice of the existing NBS programme, as well as knowledge and opinions of an expanded NBS programme. No personal identifiers were included in the questionnaire and questions were mostly in a closed-ended format. Data analyses were performed using Excel 2000 (Microsoft Corp. Redmond [WA], US) and GraphPad QuickCalcs (http://graphpad. com/quickcalcs/ConfInterval1.cfm). Percentages for each question were calculated as the number of replies divided by the total number of respondents for that question. The questions and corresponding responses are shown in Table 3.

\section{Results}

\section{Pilot study recruitment}

By 31 August 2014, 2440 neonates had been recruited. The DBSs were collected from neonates aged 24 to 48 hours $(n=2064,84.6 \%), 3$ to 5 days 
TABLE I. Precision performance and local reference intervals for full-term babies for two commercial assay kits (NeoBase, MassChrom)

\begin{tabular}{|c|c|c|c|c|c|}
\hline & \multicolumn{3}{|c|}{ NeoBase } & \multicolumn{2}{|c|}{ MassChrom } \\
\hline & $\begin{array}{l}\text { Reference interval } \\
\text { ( } \mu \mathrm{mol} / \mathrm{L})\end{array}$ & $\begin{array}{l}\text { Mean precision by } \\
\text { autopuncher (\%) }\end{array}$ & $\begin{array}{l}\text { Mean precision by } \\
\text { DBS-MS } 500(\%)\end{array}$ & $\begin{array}{l}\text { Reference interval } \\
\text { ( } \mu \mathrm{mol} / \mathrm{L})\end{array}$ & $\begin{array}{l}\text { Mean precision by } \\
\text { manual puncher (\%) }\end{array}$ \\
\hline Alanine & $152-453$ & 5.9 & 3.6 & $159-366$ & 11.5 \\
\hline Arginine & $2.4-20$ & 6.2 & 10 & $3.8-29$ & 9.5 \\
\hline Citrulline & $7.3-25$ & 5.1 & 4.3 & $11-31$ & 9.0 \\
\hline Glycine & $216-824$ & 13.2 & 6.5 & $206-607$ & 28.9 \\
\hline Leucine & $60-167$ & 6.4 & 3.2 & $70-234$ & 8.3 \\
\hline Methionine & $11-32$ & 5.1 & 3.7 & $4.8-19$ & 8.9 \\
\hline Ornithine & $51-211$ & 4.7 & 5.9 & $63-242$ & 22.8 \\
\hline Phenylalanine & $34-83$ & 5.7 & 5.4 & $43-92$ & 7.6 \\
\hline Tyrosine & $36-164$ & 4.7 & 6.2 & $45-163$ & 10.5 \\
\hline Valine & $48-146$ & 6.1 & 3.2 & $40-198$ & 7.6 \\
\hline $\mathrm{CO}$ & 8.3-33 & 7.1 & 4.9 & $16-53$ & 8.1 \\
\hline $\mathrm{C} 2$ & $8.1-34$ & 6.5 & 3.3 & $5.7-45$ & 7.6 \\
\hline C3 & $0.51-2.5$ & 5.9 & 3.0 & $0.62-3.5$ & 8.0 \\
\hline C4 & $0.08-0.33$ & 5.4 & 5.3 & $0.11-0.35$ & 8.3 \\
\hline C5 & $0.04-0.16$ & 9.7 & 5.4 & $0.07-0.33$ & 8.8 \\
\hline C5DC & $0.06-0.21$ & 8.0 & 4.7 & $0.10-0.35$ & 14.7 \\
\hline C6 & $0.02-0.09$ & 6.9 & 6.9 & $0.03-0.09$ & 7.5 \\
\hline C8 & $0.03-0.3$ & 6.1 & 8.1 & $0.03-0.13$ & 16.9 \\
\hline C10 & $0.03-0.18$ & 5.8 & 8.1 & $0.04-0.21$ & 15.4 \\
\hline C12 & $0.04-0.22$ & 12.2 & 8.2 & $0.04-0.23$ & 10.6 \\
\hline C14 & $0.1-0.39$ & 6.3 & 8.3 & $0.08-0.23$ & 9.3 \\
\hline C16 & $1.1-5.0$ & 5.7 & 11.1 & $0.77-4.84$ & 8.9 \\
\hline C18 & $0.37-1.6$ & 6.4 & 15.4 & $0.26-1.24$ & 8.1 \\
\hline
\end{tabular}

$(\mathrm{n}=331,13.6 \%), 5$ to 7 days $(\mathrm{n}=9,0.4 \%)$, and 7 to 28 days $(\mathrm{n}=36,1.5 \%)$. The participation rate was $86.6 \%$ on the days when blood samples were collected. There were no recorded DBS sampling or dispatch failures. The method validation and results of the DBS amino acids and acylcarnitine assays have been published elsewhere ${ }^{28}$; further details are available from the corresponding author on request. Overall, no true-positive cases were found in this pilot study, likely because of the limited sample size. Six $(0.25 \%)$ false-positive cases were detected in 2440 neonates; of these, two had mild elevations in long-chain acylcarnitine levels, two had high tyrosine levels, one had a high citrulline level, and one had a low free carnitine level. Subsequent laboratory findings were all normal. No false-negative cases were reported from the IEM clinics of the involved hospitals within 2 years after project completion. However, patients who emigrated or received treatment at private institutions could not be followed up.

\section{Health care professionals' knowledge and opinions of newborn screening for inborn errors of metabolism}

A total of 430 questionnaires were distributed and
$210(48.8 \%)$ completed responses were received. Results are shown in Table 3. Of the respondents, $50.0 \%$ were nurses and $32.9 \%$ were doctors. The doctors worked mainly in departments of paediatrics (47.8\%), pathology (21.7\%), and obstetrics (17.4\%). Most (89.6\%) respondents were aware of the existing NBS programme for hypothyroidism and G6PD deficiency; however, $47.5 \%$ did not know about IEM and $73.6 \%$ had not heard of expanded NBS for IEM. Most (87.6\%) respondents agreed that more education on IEM and NBS is needed.

\section{Discussion}

This is the first prospective pilot study on NBS for IEM in Hong Kong, and it has successfully evaluated the feasibility of the OPathPaed model. This study is also the first to investigate the knowledge and opinions on NBS for IEM of local health care professionals.

To implement an expanded NBS programme for IEM successfully in Hong Kong, there are several important points that need to be addressed. First, awareness and knowledge of NBS for IEM among the general public and among health care professionals should be improved. ${ }^{27}$ Second, comprehensive data 
TABLE 2. Disease panel included in the study"

\begin{tabular}{|c|c|c|c|}
\hline \multirow[t]{2}{*}{ Disease } & \multicolumn{2}{|c|}{ RUSP 2016} & \multirow[t]{2}{*}{ Treatment } \\
\hline & Core & Secondary & \\
\hline
\end{tabular}

1. Hyperphenylalaninaemias

Phenylalanine hydroxylase deficiency (classic

$\mathrm{Y} \quad$ Low phenylalanine diet \pm medication $(\mathrm{BH} 4)$ phenylketonuria) ${ }^{*}$

Disorders of biopterin biosynthesis (GTP cyclohydrolase I deficiency*, 6-pyruvoyl-tetrahydropterin synthase deficiency $^{*}$, sepiapterin reductase deficiency) and regeneration (dihydropteridine reductase deficiency and pterin- $4 \alpha$-carbinolamine dehydratase deficiency)

2. Tyrosinaemia type $\mathrm{I}^{*}$

Tyrosinaemia types II, III

3. Maple syrup urine disease*

4. Homocystinuria* (cystathionine $\beta$-synthase deficiency)

5. Hypermethioninaemia*

6. Argininosuccinic acidaemia*

7. Citrullinaemia type $I^{\star}$ Y

8. Citrullinaemia type II/citrin deficiency*

9. Argininaemia*

10. Isovaleric acidaemia*

11. Methylmalonic acidaemias* (methylmalonyl-CoA mutase deficiency; disorders of intracellular cobalamin A/B metabolism)

Disorders of intracellular cobalamin C/D metabolism

12. Propionic acidaemia*

13. Malonic acidaemia

14. Glutaric acidaemia type $I^{\star}$

Y

15. Beta-ketothiolase deficiency ${ }^{\star}$

16. Biotinidase deficiency*

$\mathrm{Y}$

Y

17. Holocarboxylase synthetase deficiency* (multiple carboxylase deficiency)

18. 3-Hydroxy-3-methylglutaryl-CoA lyase deficiency

19. Isobutyryl-CoA dehydrogenase deficiency

20. 2-Methyl-3-hydroxybutyryl-CoA dehydrogenase deficiency

21. 3-Methylglutaconyl-CoA hydratase deficiency
Y Depending on the type of tetrahydrobiopterin deficiency; may involve: (1) normalising phenylalanine levels by diet/BH4; (2) normalising neurotransmitters with L-dopa/carbidopa and 5-hydroxytryptophan; and (3) folinic acid to restore cerebral folate levels in DHPR deficiency

Medication (nitisinone) and dietary phenylalanine and tyrosine restriction

Y Dietary phenylalanine and tyrosine restriction

Diet low in branched chain amino acids \pm thiamine; sick day management

Low methionine diet, \pm pyridoxine, \pm betaine, folate and cobalamin

Y Low methionine diet

Dietary protein restriction, arginine supplement, sodium benzoate, sodium phenylbutyrate; sick day management

Dietary protein restriction, arginine supplement, sodium benzoate, sodium phenylbutyrate; sick day management

Y Lactose-free formula and a diet rich in protein and mediumchain triglycerides; fat soluble vitamins

Y Dietary protein restriction, sodium benzoate, sodium phenylbutyrate; sick day management

Low-leucine diet; levocarnitine; glycine; sick day management Low-protein diet with special formula; for adequate amino acid supply; levocarnitine; metronidazole; sick day management; also hydroxocobalamin in cobalamin-responsive methylmalonic acidaemia

Y

Low-protein diet with special formula; for adequate amino acid supply; levocarnitine; metronidazole; sick day management

Levocarnitine; high-carbohydrate and low long-chain triglycerides diet, supplementing with medium-chain triglycerides; avoid fasting; sick day management

Low protein of lysine restricted diet; levocarnitine; sick day management

Avoid fasting; low-isoleucine diet; avoid high fat intake; frequent feeding with carbohydrate-rich meals; sick day management

Biotin supplement

Biotin supplement

Avoid fasting; low leucine and fat but high carbohydrate diet; uncooked cornstarch with special formula may be used; levocarnitine; sick day management

Avoid fasting, low valine diet, levocarnitine if deficient; sick day management

Y Avoid fasting, low isoleucine diet; levocarnitine if deficient; sick day management

Y Avoid fasting, low leucine diet; levocarnitine; sick day management

Abbreviations: $\mathrm{BH} 4$ = tetrahydrobiopterin; DHPR = dihydropteridine reductase; $M A D D=$ multiple acyl-CoA dehydrogenation deficiency; RUSP = recommended uniform screening panel

* Diseases have been reported in local patients 8,10 
TABLE 2. (cont'd)

\begin{tabular}{|c|c|c|c|}
\hline \multirow[t]{2}{*}{ Disease } & \multicolumn{2}{|c|}{ RUSP 2016} & \multirow[t]{2}{*}{ Treatment } \\
\hline & Core & Secondary & \\
\hline 22. 2-Methylbutyryl-CoA dehydrogenase deficiency & & $\mathrm{Y}$ & $\begin{array}{l}\text { Avoid fasting, low isoleucine diet; levocarnitine if deficient; } \\
\text { sick day management }\end{array}$ \\
\hline $\begin{array}{l}\text { 23. Multiple acyl-CoA dehydrogenase deficiency (glutaric } \\
\text { acidaemia type II)* }\end{array}$ & & $\mathrm{Y}$ & $\begin{array}{l}\text { Regular meals; fat reduced and less protein reduced diet; } \\
\beta \text {-hydroxybutyrate; riboflavin for riboflavin responsive MADD; } \\
\text { sick day management }\end{array}$ \\
\hline 24. Primary carnitine deficiency* & Y & & $\begin{array}{l}\text { Avoid prolonged fasting; normal diet, regular meals; carnitine } \\
\text { replacement }\end{array}$ \\
\hline 25. Carnitine palmitoyltransferase type IA deficiency & & $\mathrm{Y}$ & \multirow{3}{*}{$\begin{array}{l}\text { Avoid prolonged fasting; frequent regular meals; high- } \\
\text { carbohydrate diet, long-chain fat restriction; medium-chain } \\
\text { triglycerides; sick day management; emergency treatment } \\
\text { protocol }\end{array}$} \\
\hline 26. Carnitine palmitoyltransferase type II deficiency* & & $\mathrm{Y}$ & \\
\hline 27. Carnitine acylcarnitine translocase deficiency* & & $\mathrm{Y}$ & \\
\hline $\begin{array}{l}\text { 28. Very long-chain acyl-coenzyme A dehydrogenase } \\
\text { deficiency }^{*}\end{array}$ & $\mathrm{Y}$ & & \\
\hline $\begin{array}{l}\text { 29. Medium-chain acyl-coenzyme A dehydrogenase } \\
\text { deficiency }^{\star}\end{array}$ & $\mathrm{Y}$ & & Avoid prolonged fasting; regular meals, sick day management \\
\hline $\begin{array}{l}\text { 30. Medium/short-chain L-3-hydroxyacyl-CoA } \\
\text { dehydrogenase deficiency }\end{array}$ & & $\mathrm{Y}$ & $\begin{array}{l}\text { Avoid prolonged fasting; regular meals, sick day management; } \\
\text { glucagon, somatostatin, diazoxide if associated with } \\
\text { hyperinsulinaemic hypoglycaemia }\end{array}$ \\
\hline $\begin{array}{l}\text { 31. Long-chain 3-hydroxyacyl-CoA dehydrogenase } \\
\text { deficiency }\end{array}$ & $\mathrm{Y}$ & & \multirow{2}{*}{$\begin{array}{l}\text { Avoid prolonged fasting; frequent regular meals; high- } \\
\text { carbohydrate diet, long-chain fat restriction; medium chain } \\
\text { triglycerides; sick day management; emergency treatment } \\
\text { protocol }\end{array}$} \\
\hline 32. Trifunctional protein deficiency & Y & & \\
\hline
\end{tabular}

on the local disease spectrum and incidence should be made available; such data were not available until recently. ${ }^{3,5}$ Third, free flow of information and sharing of experiences among colleagues working in the acute care and public health sectors should be facilitated. Fourth, more emphasis should be given to regular updates on NBS health care policy, confirmatory investigation service support, and treatment protocols. Last, the use of umbilical cord blood samples in the existing programme is unsuitable for an expanded NBS programme for IEM because of unacceptably high false-negative rates. ${ }^{29}$ The metabolites associated with many amino acid disorders, organic acid disorders, and fatty acid oxidation disorders are not elevated in cord blood. In 2013, the hospital-based OPathPaed model was published for the implementation of an expanded NBS programme suitable for a local setting. ${ }^{19}$ The present study further confirms the feasibility of the OPathPaed model for use on a larger scale. The OPathPaed model integrates expert input from obstetricians, pathologists, and paediatricians. Because babies born in Hong Kong are normally delivered in hospitals, the OPathPaed model approach should be able to achieve full coverage.

The success of an expanded NBS programme for IEM would depend not only on the diagnostics but also on how well patients diagnosed with IEM could be managed. It is difficult to accumulate experience and the many metabolic diseases can easily cause confusion. In addition, sophisticated management requires individualised drug formulations, which may not be easily accessible or may involve offlabel prescriptions. Overseas studies have identified significant knowledge gaps among clinicians involved in the follow-up care of newborns with IEM identified by NBS. ${ }^{15-18}$ Some were poorly prepared to follow up the initial diagnosis, provide appropriate counselling, or make appropriate clinical referrals. ${ }^{17}$ In our study, $73.6 \%$ of 210 health care professionals (who were not involved in the pilot study) were unaware of the expanded NBS programme, and $47.5 \%$ of respondents did not know what IEM were. The majority of respondents (87.6\%) agreed that better education was needed and $91.3 \%$ supported expanding NBS for IEM immediately or within 3 years. According to a parental survey among 172 parents regarding NBS for IEM, ${ }^{27}$ over $89 \%$ had never heard of NBS for IEM or metabolic disorders. Although some IEM may be incurable, 97\% of parents supported an expanded NBS programme and $82.8 \%$ of parents supported implementation of this expansion immediately or within 3 years. ${ }^{27}$

The present study also provides the first local evaluation of the fully automated DBS-MS 500 system. The DBS is directly eluted into the extraction chamber, with an online extraction system connecting with the tandem mass spectrometer. There is no need for DBS card punching. Together with the integrated optical card recognition and barcode reading module, this automation minimises the risk of sample misidentification during manual processing. The precision and accuracy demonstrated are comparable to those of conventional procedures. 
TABLE 3. Survey questions on knowledge and opinions of newborn screening for inborn errors of metabolism and responses from health care professionals in Hong Kong $(n=210)$ *

\begin{tabular}{|c|c|c|c|c|}
\hline \multicolumn{3}{|c|}{ Demographics } & \multicolumn{2}{|l|}{ Data } \\
\hline \multicolumn{5}{|c|}{ Staff } \\
\hline \multicolumn{2}{|c|}{ Doctors } & & \multicolumn{2}{|c|}{$69(32.9)$} \\
\hline \multicolumn{2}{|c|}{ Nurses } & & \multicolumn{2}{|c|}{$105(50.0)$} \\
\hline \multicolumn{3}{|c|}{ Allied health } & \multicolumn{2}{|c|}{$36(17.1)$} \\
\hline \multicolumn{5}{|c|}{ Specialty (for doctors only) } \\
\hline \multicolumn{3}{|c|}{ Paediatrics } & \multicolumn{2}{|c|}{$33(47.8)$} \\
\hline \multicolumn{3}{|c|}{ Pathology } & \multicolumn{2}{|c|}{$15(21.7)$} \\
\hline \multicolumn{3}{|c|}{ Obstetrics } & \multicolumn{2}{|c|}{$12(17.4)$} \\
\hline \multicolumn{3}{|c|}{ Family medicine } & \multicolumn{2}{|l|}{$1(1.4)$} \\
\hline \multicolumn{3}{|c|}{ Others $†$} & \multicolumn{2}{|c|}{$8(11.6)$} \\
\hline \multicolumn{5}{|c|}{ Working experience (for all respondents), y } \\
\hline \multicolumn{3}{|c|}{$<5$} & \multicolumn{2}{|c|}{$56(26.7)$} \\
\hline \multicolumn{3}{|c|}{5 to $<10$} & \multicolumn{2}{|c|}{$46(21.9)$} \\
\hline \multicolumn{3}{|c|}{10 to $<15$} & \multicolumn{2}{|c|}{$30(14.3)$} \\
\hline \multicolumn{3}{|c|}{$\geq 15$} & \multicolumn{2}{|c|}{$78(37.1)$} \\
\hline \multicolumn{2}{|c|}{ Question } & Yes & No & Missing data \\
\hline & $\begin{array}{l}\text { Do you know what conditions of the existing NBS are } \\
\text { included in Hong Kong? } \\
\text { If yes, which condition(s) are included? (can tick more than } \\
\text { one) } \\
\text { i. Congenital hypothyroidism } \\
\text { ii. Glucose-6-phosphate dehydrogenase deficiency } \\
\text { iii. Congenital deafness } \\
\text { iv. Phenylketonuria (hyperphenylalaninaemia) } \\
\text { v. Cystic fibrosis }\end{array}$ & $\begin{array}{l}179(99.4,96.60-99.99) \\
165(91.7,86.62-94.97) \\
137(76.1,69.35-81.78) \\
17(9.4,5.90-14.68) \\
11(6.1,3.33-10.72)\end{array}$ & $\begin{aligned} & 1(0.6,<0.01-3.40) \\
& 12(6.7,3.75-11.40) \\
& 35(19.4,14.29-25.87) \\
& 147(81.7,75.33-86.68) \\
& 154(85.6,79.62-90.00)\end{aligned}$ & 9 \\
\hline Q2. & Have you heard of expanded NBS for IEM before? & $55(26.4,20.90-32.84)$ & $153(73.6,67.16-79.10)$ & 2 \\
\hline & $\begin{array}{l}\text { Do you know what IEM are? Grade your knowledge from } 0 \\
\text { (worst) to } 10 \text { (best understanding) } \\
0 \\
1 \\
2 \\
3 \\
4 \\
5 \\
6 \\
7 \\
8 \\
9 \\
10\end{array}$ & $\begin{aligned} 106 & (52.5,45.61-59.25) \\
& \\
2 & (1.9,0.10-7.04) \\
1 & (0.9,<0.01-5.67) \\
10 & (9.4,5.04-16.67) \\
14 & (13.2,7.91-21.08) \\
13 & (12.3,7.18-19.99) \\
26 & (24.5,17.28-33.56) \\
12 & (11.3,6.45-18.89) \\
12 & (11.3,6.45-18.89) \\
9 & (8.5,4.35-15.54) \\
5 & (4.7,1.76-10.84) \\
2 & (1.9,0.10-7.04)\end{aligned}$ & $96(47.5,40.75-54.39)$ & 8 \\
\hline Q4. & Is more education on expanded NBS and IEM required? & $183(87.6,82.35-91.42)$ & $26(12.4,8.58-17.65)$ & 1 \\
\hline & $\begin{array}{l}\text { The incidences of IEM in mainland China and Hong Kong are } \\
\text { similar. In mainland China, the screening programme also } \\
\text { includes hyperphenylalaninaemia and more conditions in } \\
\text { some advanced provinces. Do you think Hong Kong should } \\
\text { follow the mainland China policy of expanded NBS? }\end{array}$ & $148(71.2,64.65-76.89)$ & $60(28.8,23.11-35.35)$ & 2 \\
\hline Q6. & $\begin{array}{l}\text { The average annual birth rate is around } 80000 \text { in Hong Kong. } \\
\text { With the incidence of } 1 \text { in } 4122 \text {, there will be about } 20 \text { IEM } \\
\text { patients born each year. Do you think the number is justified } \\
\text { for a population screening? If yes, when do you think it is } \\
\text { proper to implement NBS for IEM in Hong Kong? } \\
\text { i. Immediately } \\
\text { ii. } 3 \text { Years later } \\
\text { iii. } 5 \text { Years later }\end{array}$ & $\begin{array}{l}72(48.0,40.15-55.94) \\
65(43.3,35.67-51.33) \\
13(8.7,5.02-14.38)\end{array}$ & $55(26.8,21.22-33.29)$ & 5 \\
\hline
\end{tabular}

Abbreviations: IEM = inborn errors of metabolism; NBS = newborn screening

* Data are shown as No., No. (\%), or No. (\%, 95\% confidence interval)

† Others include internal medicine, surgery, orthopaedics, ophthalmology, radiology, and allied health 
TABLE 3. (cont'd)

\begin{tabular}{|c|c|c|c|c|}
\hline \multicolumn{2}{|c|}{ Question } & $\frac{\text { Yes }}{141(70.9,64.18-76.74)}$ & \multirow{2}{*}{$\frac{\text { No }}{58(29.1,23.26-35.82)}$} & $\frac{\text { Missing data }}{11}$ \\
\hline Q7. & $\begin{array}{l}\text { Some IEMs are amenable to treatment with good outcome, } \\
\text { but some do not. Do you support the screening of these } \\
\text { incurable conditions and why? } \\
\text { If yes (can choose more than } 1 \text { option): } \\
\text { i. Prevention of delayed diagnosis } \\
\text { ii. Better preparation for lifestyle } \\
\text { iii. Assist family planning } \\
\text { iv. Avoid medicolegal complaints } \\
\text { v. Others } \\
\text { If no (can choose more than } 1 \text { option): } \\
\text { i. Unnecessary intervention } \\
\text { ii. Fear of discrimination } \\
\text { iii. Anxiety } \\
\text { iv. Others }\end{array}$ & $\begin{aligned} 125 & (88.7,82.27-92.99) \\
98 & (69.5,61.45-76.52) \\
119 & (84.4,77.44-89.53) \\
44 & (31.2,24.13-39.28) \\
3 & (2.1,0.45-6.35)\end{aligned}$ & & 11 \\
\hline Q8. & Should the NBS be voluntary or mandatory? & $\begin{array}{c}\text { Voluntary } \\
133(64.9,58.12-71.09)\end{array}$ & $\begin{array}{c}\text { Mandatory } \\
72(35.1,28.91-41.88)\end{array}$ & 5 \\
\hline Q9. & $\begin{array}{l}\text { Is parent consent necessary before blood sampling of the } \\
\text { baby? }\end{array}$ & $164(78.8,72.77-83.87)$ & $44(21.2,16.13-27.23)$ & 2 \\
\hline Q10. & $\begin{array}{l}\text { Would you recommend a pre-test counselling before blood } \\
\text { sampling of the baby? }\end{array}$ & $161(77.4,71.23-82.58)$ & $47(22.6,17.42-28.77)$ & 2 \\
\hline Q11. & Should the NBS for IEM be totally funded by the government? & $131(63.9,57.12-70.17)$ & $74(36.1,29.83-42.88)$ & 5 \\
\hline Q12. & $\begin{array}{l}\text { Are you willing to refer patients for NBS for IEM if it is available } \\
\text { in private sectors? }\end{array}$ & $182(87.9,82.73-91.74)$ & $25(12.1,8.26-17.27)$ & 3 \\
\hline Q13. & $\begin{array}{l}\text { The test results may not be } 100 \% \text { correct with the possibilities } \\
\text { of false positive and false negative risks. Babies with positive } \\
\text { results are required for further investigations. Do you think it is } \\
\text { still worthwhile for screening? }\end{array}$ & $165(78.9,72.90-83.95)$ & $44(21.1,16.05-27.10)$ & 1 \\
\hline
\end{tabular}

However, because the DBS-MS 500 system requires application of an internal standard solution before extraction, the financial cost per extraction would be higher than that for conventional methods. In addition, special DBS cards are required for the extraction chamber. Third-party DBS cards of a specific quality may not easily fit into the system. The throughput of up to 500 DBS cards per run is more than adequate for local needs, as there are about 50000 live births annually in Hong Kong.

The limitations of the pilot study include small and non-representative sample size, a relatively short study period that may have been inadequate for follow-up to confirm true negatives, and the convenience sampling and low response rate of the health care professional survey.

\section{Conclusion}

The present pilot study investigated the feasibility of an expanded NBS for IEM in Hong Kong, and surveyed health care professionals for their knowledge and opinions on NBS for IEM. We successfully evaluated the OPathPaed model on a larger scale than has been attempted previously and demonstrated that health care professionals have a favourable opinion of implementing an expanded NBS programme in Hong Kong. It is timely that, as this pilot study was completed, the needs of parents and health care workers were addressed in the Hong Kong Special Administrative Region Chief Executive's Policy Address of 2015, when a government-led initiative was announced to study the feasibility of NBS for IEM in the public health care system on a large scale.

\section{Author contributions}

All authors have made substantial contributions to the concept or design of this study; acquisition of data; analysis or interpretation of data; drafting of the article; and critical revision for important intellectual content.

\section{Acknowledgement}

We acknowledge all collaborators, doctors, nurses, medical technologists, phlebotomists, information technologists, and parents for their efforts and support. We thank the Save Babies Through Screening Foundation for allowing us to use their video for educational purpose. We thank CAMAG Germany for providing technical support during the evaluation of the DBS-MS 500. The CAMAG had no role in the study design, data collection, analysis, reporting, or manuscript preparation.

\section{Funding/support}

This work was funded by the SK Yee Medical Foundation. The funder had no role in study design, data collection, analysis, interpretation, or manuscript preparation.

\section{Declaration}

All authors have no conflicts of interest to disclose. All authors had full access to the data, contributed to the study, approved 
the final version for publication, and take responsibility for its accuracy and integrity.

\section{Ethical approval}

Local ethical approval was obtained from each of the regional hospitals involved in this study.

\section{References}

1. Millington DS, Kodo N, Norwood DL, Roe CR. Tandem mass spectrometry: a new method for acylcarnitine profiling with potential for neonatal screening for inborn errors of metabolism. J Inherit Metab Dis 1990;13:321-4.

2. Carpenter $\mathrm{KH}$, Wiley V. Application of tandem mass spectrometry to biochemical genetics and newborn screening. Clin Chim Acta 2002;322:1-10.

3. Lee HC, Mak CM, Lam CW, et al. Analysis of inborn errors of metabolism: disease spectrum for expanded newborn screening in Hong Kong. Chin Med J (Engl) 2011;124:9839.

4. Davies DP. Hong Kong Reflections: Health, Illness and Disability in Hong Kong Children. Hong Kong: The Chinese University Press; 1995.

5. Hui J, Tang NL, Li CK, et al. Inherited metabolic diseases in the Southern Chinese population: spectrum of diseases and estimated incidence from recurrent mutations. Pathology 2014;46:375-82.

6. Gu X, Wang Z, Ye J, Han L, Qiu W. Newborn screening in China: phenylketonuria, congenital hypothyroidism and expanded screening. Ann Acad Med Singapore 2008;37(12 Suppl):107-10.

7. Niu DM, Chien YH, Chiang CC, et al. Nationwide survey of extended newborn screening by tandem mass spectrometry in Taiwan. J Inherit Metab Dis 2010;33(Suppl 2):S295-305.

8. Chace DH, Kalas TA, Naylor EW. The application of tandem mass spectrometry to neonatal screening for inherited disorders of intermediary metabolism. Annu Rev Genomics Hum Genet 2002;3:17-45.

9. Zheng S, Song M, Wu L, et al. China: public health genomics. Public Health Genomics 2010;13:269-75.

10. American College of Medical Genetics Newborn Screening Expert Group. Newborn screening: toward a uniform screening panel and system-executive summary. Pediatrics 2006;117(5 Pt 2):S296-307.

11. Recommended Uniform Screening Panel, The Advisory Committee on Heritable Disorders in Newborns and Children, US Department of Health and Human Services. Available from: https:/www.hrsa.gov/ advisorycommittees/mchbadvisory/heritabledisorders/ recommendedpanel/. Accessed 1 Aug 2017.

12. Therrell BL, Johnson A, Williams D. Status of newborn screening programs in the United States. Pediatrics 2006;117(5 Pt 2):S212-52.

13. Lee HC, Lai CK, Siu TS, et al. Role of postmortem genetic testing demonstrated in a case of glutaric aciduria type II. Diagn Mol Pathol 2010;19:184-6.

14. Coroners' Report 2008. Available from: http://www. judiciary.hk/en/publications/coroner_report_july08.pdf. Accessed 1 Aug 2017.
15. Gennaccaro M, Waisbren SE, Marsden D. The knowledge gap in expanded newborn screening: survey results from paediatricians in Massachusetts. J Inherit Metab Dis 2005;28:819-24.

16. Wells AS, Northrup H, Crandell SS, et al. Expanded newborn screening in Texas: a survey and educational module addressing the knowledge of pediatric residents. Genet Med 2009;11:163-8.

17. Kemper AR, Uren RL, Moseley KL, Clark SJ. Primary care physicians' attitudes regarding follow-up care for children with positive newborn screening results. Pediatrics 2006;118:1836-41.

18. Dunn L, Gordon K, Sein J, Ross K. Universal newborn screening: knowledge, attitudes, and satisfaction among public health professionals. South Med J 2012;105:218-22.

19. Mak CM, Lam C, Siu W, et al. OPathPaed service model for expanded newborn screening in Hong Kong SAR, China. Br J Biomed Sci 2013;70:84-8.

20. 一滴血驗出罕見遺傳病. Oriental Daily 2010 Sep 12. Available from: http://orientaldaily.on.cc/cnt/ news/20100912/00176_002.html. Accessed 1 Aug 2017.

21. 二代新生嬰兒篩檢代謝疾病. am730 2013 May 6. Available from: http://archive.am730.com.hk/column-153216. Accessed 1 Aug 2017.

22. 篩查防智障代謝病, 社會可年省近千萬. Ming Pao 2014 Jun 9. Available from: https://news.mingpao.com/pns/ 篩查防智障代謝病 \% 20 社會可年省近千萬/web_tc/ article/20140609/s00002/1402257010439. Accessed 1 Aug 2017.

23. 精靈一點 (RTHK radio programme, 2014 Apr 15). Available from: http://programme.rthk.hk/channel/radio/ programme.php? name $=$ radio $1 /$ adwiser $\& d=2014-04-$ $15 \& \mathrm{p}=1147 \& \mathrm{e}=259149 \& \mathrm{~m}=$ episode. Accessed 1 Aug 2017. 24. 星期二檔案 : 這幾滴血 (TVB programme, 2014 Feb 25). Available from: http://programme.tvb.com/news/ tuesdayreport/episode/20140225/\#page-1. Accessed 1 Aug 2017.

25. NBS01-A6, Blood Collection on Filter Paper for Newborn Screening Programs; Approved Standard-Sixth Edition. Available from: https://clsi.org/standards/products/ newborn-screening/documents/nbs01/. Accessed 1 Aug 2017.

26. Lee HH, Mak CM, Poon GW, Wong KY, Lam CW. Cost-benefit analysis of hyperphenylalaninemia due to 6-pyruvoyl-tetrahydropterin synthase (PTPS) deficiency: for consideration of expanded newborn screening in Hong Kong. J Med Screen 2014;21:61-70.

27. Mak CM, Lam CW, Law CY, et al. Parental attitudes on expanded newborn screening in Hong Kong. Public Health 2012;126:954-9.

28. Mak M. Chemical pathology analysis of inborn errors of metabolism for expanded newborn screening in Hong Kong [thesis]. The University of Hong Kong; 2012. Available from: http://hub.hku.hk/handle/10722/180075. Accessed 1 Aug 2017.

29. Walter JH, Patterson A, Till J, Besley GT, Fleming G, Henderson MJ. Bloodspot acylcarnitine and amino acid analysis in cord blood samples: efficacy and reference data from a large cohort study. J Inherit Metab Dis 2009;32:95101. 